\title{
Partial B-to-A DNA Transition upon Minor Groove Binding of Protein Sac7d Monitored by Raman Spectroscopy ${ }^{\dagger}$
}

\author{
Lubomír Dostál, ${ }^{\ddagger}$ Chin-Yu Chen, ${ }^{\S, \|}$ Andrew H.-J. Wang, ${ }^{\S}$ and Heinz Welfle*,\$ \\ AG Biopolymerspektroskopie, Max-Delbrück-Centrum für Molekulare Medizin Berlin-Buch, Robert-Rössle-Straße 10, \\ D-13092 Berlin, Germany; Institute of Biological Chemistry, Academia Sinica, 128 Academia Road, Sec. 2, Nankang, \\ Taipei 115, Taiwan; and Department of Chemistry, National Taiwan University, Taipei 106, Taiwan
}

Received April 22, 2004; Revised Manuscript Received May 27, 2004

\begin{abstract}
Members of the Sso7d/Sac7d protein family and other related proteins are believed to play an important role in DNA packaging and maintenance in archeons. Sso7d/Sac7d are small, abundant, basic, and nonspecific DNA-binding proteins of the hyperthermophilic archeon Sulfolobus. Structures of several complexes of Sso7d/Sac7d with DNA octamers are known. These structures are characterized by sequence unspecific minor groove binding of the proteins and sharp kinking of the double helix. Corresponding Raman vibrational signatures have been identified in this study. A Raman spectroscopic analysis of Sac7d binding to the oligonucleotide decamer d(GAGGCGCCTC $)_{2}$ reveals large conformational perturbations in the DNA structure upon complex formation. Perturbed Raman bands are associated with the vibrational modes of the sugar phosphate backbone and frequency shifts of bands assigned to nucleoside vibrations. Large changes in the DNA backbone and partial B- to A-form DNA transitions are indicated that are closely associated with $\mathrm{C} 2$ '-endo/anti to $\mathrm{C} 3$ '-endo/anti conversion of the deoxyadenosyl moiety upon Sac7d binding. The major spectral feature of Sac7d binding is kinking of the DNA. Raman markers of minor groove binding do not largely contribute to spectral differences; however, clear indications for minor groove binding come from G-N2 and G-N3 signals that are supported by Trp24 features. Trp24 is the only tryptophan present in Sac7d and binds to guanine N3, as has been demonstrated clearly in X-ray structures of Sac7d-DNA complexes. No changes of the Sac7d secondary structure have been detected upon DNA binding.
\end{abstract}

Complex formation with DNA-binding proteins drives DNA superhelicity, which in turn regulates the double helix stability. DNA in eubacteria and eukarya is overall negatively supercoiled due to gyrase action and wrapped around the histone core of the nucleosome. In contrast, episomal DNAs in thermophilic archaea are relaxed to positively supercoiled forms $(1,2)$. In archaea the mechanism for organizing DNA into a compact form is not well understood. Members of the Sso7d/Sac7d protein family and other related proteins are believed to play an important role in DNA packaging and maintenance. Sso7d/Sac7d are small, abundant, basic, and nonspecific DNA-binding proteins of the hyperthermophilic archeon Sulfolobus $(3,4)$.

Sso7d/Sac7d bind to DNA noncooperatively with micromolar affinity, without strong sequence preference, and the $T_{\mathrm{m}}$ values of Sac7-DNA complexes are $\sim 40{ }^{\circ} \mathrm{C}$ higher than those of free DNA (5). The structures of several Sac7d/ Sso7d-DNA complexes have been studied by X-ray crystallography (6-8), NMR (9), and low-angle X-ray scattering

$\dagger$ This work was supported by the Deutsche Forschungsgemeinschaft (Graduiertenkolleg GK 80/1 to H.W.).

* To whom correspondence should be addressed. E-mail: welfle@ mdc-berlin.de. Fax/Telephone: +49-30-9406 2840. Mailing address: Dr. Heinz Welfle, Max-Delbrück-Centrum für Molekulare Medizin Berlin-Buch, Postfach 740238, D-13092 Berlin, Germany.

$\doteqdot$ Max-Delbrück-Centrum für Molekulare Medizin Berlin-Buch.

\& Academia Sinica.

"National Taiwan University.

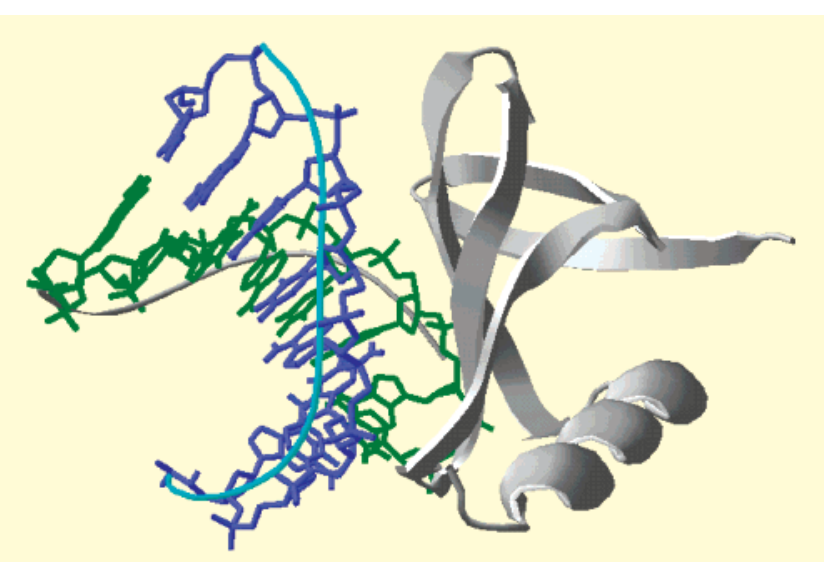

Figure 1: Model of the Sac7d-d(GCGATCGC) $)_{2}$ complex. The figure was prepared using SPDBV (DeepView/Swiss-PdbViewer from http://www.expasy.org/spdb/) and the atomic coordinates from the pdb file $1 \mathrm{AZP}$.

(10). Figure 1 shows a model of the Sac7d-DNA complex with octamer d(GCGATCGC) $)_{2}(6)$.

In the protein-DNA complexes, the protein structures are similar to those of the free proteins $(3,11)$, consisting of an incomplete $\beta$-barrel made of a triple-stranded $\beta$-sheet orthogonal to a $\beta$-hairpin. The small $\beta$-barrel is capped by an amphiphilic C-terminal $\alpha$-helix. The triple-stranded $\beta$-sheet is placed across the DNA minor groove, and the side chains of Val26 and Met29 intercalate into DNA base pairs 
and cause a sharp kink $\left(\sim 60^{\circ}\right)$ in the DNA duplex $(6-8)$.

In the present study, we analyze by Raman spectroscopy the binding of Sac7d to the 10-bp DNA oligonucleotide d(GAGGCGCCTC $)_{2}$. A Raman difference spectrum was obtained by subtraction of the spectra of isolated Sac7d and $\mathrm{d}(\mathrm{GAGGCGCCTC})_{2}$ from the spectrum of the Sac7d$\mathrm{d}(\text { GAGGCGCCTC })_{2}$ complex, and its analysis reveals large conformational perturbations in the DNA structure induced by Sac7d protein binding.

\section{MATERIALS AND METHODS}

Chemicals. Isopropyl- $\beta$-D-thiogalactopyranoside (IPTG), ${ }^{1}$ ampicillin, and chloramphenicol were obtained from MdBio, Inc., Taipei, Taiwan. All other chemicals were purchased from Merck, Darmstadt, Germany. Superdex 200 was from Amersham-Pharmacia, Freiburg, Germany.

Preparation of Sac7d, d(GAGGCGCCTC $)_{2}$, and the Sac7d$d(G A G G C G C C T C)_{2}$ Complex for Raman Measurements. Recombinant Sac7d was overexpressed in E. coli, after induction with IPTG, and purified as described elsewhere (4). The purified protein was dialyzed against deionized water and lyophylized. Before Raman measurements the Sac7d protein was dissolved in $50 \mathrm{mM}$ Tris- $\mathrm{HCl} \mathrm{pH} 7.5,50 \mathrm{mM}$ $\mathrm{NaCl}$, and $10 \mathrm{mM} \mathrm{MgCl} 2$ (buffer I) and filtered through a Superdex 200 column, equilibrated with buffer I. The protein samples were concentrated in Centricon YM-3, 3000 MWCO Millipore tubes. Protein concentrations were determined by UV absorbance using an extinction coefficient of $\epsilon_{278 \mathrm{~nm}}=$ $8400 \mathrm{M}^{-1} \cdot \mathrm{cm}^{-1}$ calculated from the amino acid sequence with the Expasy server.

Oligonucleotides were purchased from BioTez, Berlin, Germany. Concentrations of DNA were determined spectrophotometrically using an extinction coefficient $\epsilon_{260 \mathrm{~nm}}=$ $14120 \mathrm{M} \cdot \mathrm{bp}^{-1} \cdot \mathrm{cm}^{-1}$ calculated from the base composition according to ref 12. Equimolar amounts of each strand were mixed, heated to $95^{\circ} \mathrm{C}$ for $10 \mathrm{~min}$, annealed by slow cooling, and purified by gel filtration using a Superdex 200 column equilibrated in buffer I. Peak fractions were concentrated in Centricon Millipore tubes YM-3, 3000 MWCO.

The Sac7d-d(GAGGCGCCTC $)_{2}$ complex was prepared by mixing Sac7d and d(GAGGCGCCTC $)_{2}$ in a 1:1 molar ratio. The samples were concentrated in a $5 \mathrm{~K}$ Millipore Ultrafree centrifugal filter device. The concentration of the complex was determined from the absorbance at $260 \mathrm{~nm}$ using the DNA extinction coefficient, neglecting the minor contribution of protein to the absorbance.

Hydrogen-Deuterium Exchange. Hydrogen-deuterium exchange was accomplished by incubation of folded Sac7d in $\mathrm{D}_{2} \mathrm{O}$ based buffer II (50 mM Tris-DCl, pD 7.5, $50 \mathrm{mM}$ $\mathrm{NaCl}$, and $10 \mathrm{mM} \mathrm{MgCl}_{2}$ ) and passing the samples through a homemade Sephadex G10 (Pharmacia) column of $2 \mathrm{~cm}$ length. The column was equilibrated in $\mathrm{D}_{2} \mathrm{O}$ with buffer II. Protein samples elute in the void volume and were fully separated from the $\mathrm{H}_{2} \mathrm{O}$ solvent with buffer I. This procedure accomplishes only $\mathrm{H} \rightarrow \mathrm{D}$ exchange $(\mathrm{OH} \rightarrow \mathrm{OD}$ and $\mathrm{NH} \rightarrow$ $\mathrm{ND}$ ) of hydrogen atoms that are not protected by covalent bonds or the native fold of the protein.

Raman Spectroscopy. Homemade quartz cuvettes were filled with approximately $12 \mu \mathrm{L}$ of the sample solution and

\footnotetext{
${ }^{1}$ Abbreviation: IPTG, isopropyl- $\beta$-D-thiogalactopyranoside.
}

then tightly closed with Teflon stoppers. The sample concentrations in $\mathrm{H}_{2} \mathrm{O}$ buffer I (the concentrations in $\mathrm{D}_{2} \mathrm{O}$ buffer II are given in parentheses) were 11 and 12 (13) mg/ $\mathrm{mL}$ for DNA, 12 and 22 (17) $\mathrm{mg} / \mathrm{mL}$ for Sac7d, and 11 and 50 (36) $\mathrm{mg} / \mathrm{mL}$ for the Sac7d-d(GAGGCGCCTC) $)_{2}$ complex. Spectra were collected at $22{ }^{\circ} \mathrm{C}$ on the Raman spectrometer T64000 (Jobin Yvon, France) in the single monoconfiguration equipped with a liquid nitrogen-cooled chargecoupled-device (CCD) detector. The 488-nm line of a Coherent Innova 90 argon ion laser with $200 \mathrm{~mW}$ of radiant power at the sample position in the macrochamber was used for the excitation of the Raman spectra. Ten spectra, each measured for $300 \mathrm{~s}$, were accumulated and averaged to produce the spectra shown in Figures 2-4. To exclude all possible drifts of the wavenumber scale during the data measurement, a calibration spectrum was collected after each 300 s sample spectra accumulation step. The calibration procedure is described in detail elsewhere (13).

Raman data analyses were performed with the software packages LabSpec (Jobin Yvon) and GRAMS (Thermo Galactic). Minimization of intensity differences between the spectra of isolated components and Sac7d-d(GAGGCGC$\mathrm{CTC})_{2}$ is crucial for the calculation of difference spectra. To achieve this, the d(GAGGCGCCTC $)_{2}$ spectrum was normalized with respect to the $\mathrm{P}-\mathrm{O}$ stretching vibration of the phosphodioxy group $\left(\mathrm{PO}_{2}^{-}\right)$near $1092 \mathrm{~cm}^{-1}$, and the Sac7d spectrum was normalized with respect to the phenyl ring vibration of phenylalanine at $1003 \mathrm{~cm}^{-1}$. Normalized but otherwise not corrected experimental spectra of d(GAGGCGCCTC $)_{2}$ and Sac7d were subtracted from the spectrum of the Sac7d-d(GAGGCGCCTC) 2 complex. In the next evaluation steps, the buffer spectrum and fluorescence background were removed. For this purpose the fluorescence background was approximated by a polynomial curve.

Difference bands were considered as significant when the following criteria are fulfilled: (i) the intensity of the difference band is at least two times higher than the signalto-noise ratio, (ii) the difference band reflects an intensity change of at least $5 \%$ of its parent band, and (iii) corresponding difference bands were obtained from spectra measured in $\mathrm{H}_{2} \mathrm{O}$ and $\mathrm{D}_{2} \mathrm{O}$ buffers.

\section{RESULTS}

\section{Raman Spectrum of d(GAGGCGCCTC $)_{2}$}

The self-complementary DNA sequence of the decameric oligonucleotide d(GAGGCGCCTC) $)_{2}$ used in this study is closely related to that of the octamers studied previously in crystal structure analyses of Sac7d-DNA complexes (6$8)$. Figure 2 shows the Raman spectra of d(GAGGCGCCTC) $)_{2}$ in $\mathrm{H}_{2} \mathrm{O}$ and $\mathrm{D}_{2} \mathrm{O}$ buffers.

Wavenumber positions of the major peaks are given in Figure 2. The peak positions are in general accordance with those of DNA given previously in the literature (14-17 and references therein).

The backbone conformation markers at 831 and $1092 \mathrm{~cm}^{-1}$ in $\mathrm{H}_{2} \mathrm{O}$ and at 828 and $1091 \mathrm{~cm}^{-1}$ in $\mathrm{D}_{2} \mathrm{O}$ are diagnostic of B-DNA (15). The positions of the nucleoside conformation markers shift upon deuteration [from 667 to $661 \mathrm{~cm}^{-1}$ (dT); 729 to $722 \mathrm{~cm}^{-1}$ (dA); 749 to $747 \mathrm{~cm}^{-1}$ (dT); 782 to 772 $\mathrm{cm}^{-1}(\mathrm{dC}) ; 1257$ to $\left.1261 \mathrm{~cm}^{-1}(\mathrm{dC})\right]$. The $683 \mathrm{~cm}^{-1} \mathrm{dG}$ marker band does not shift. 


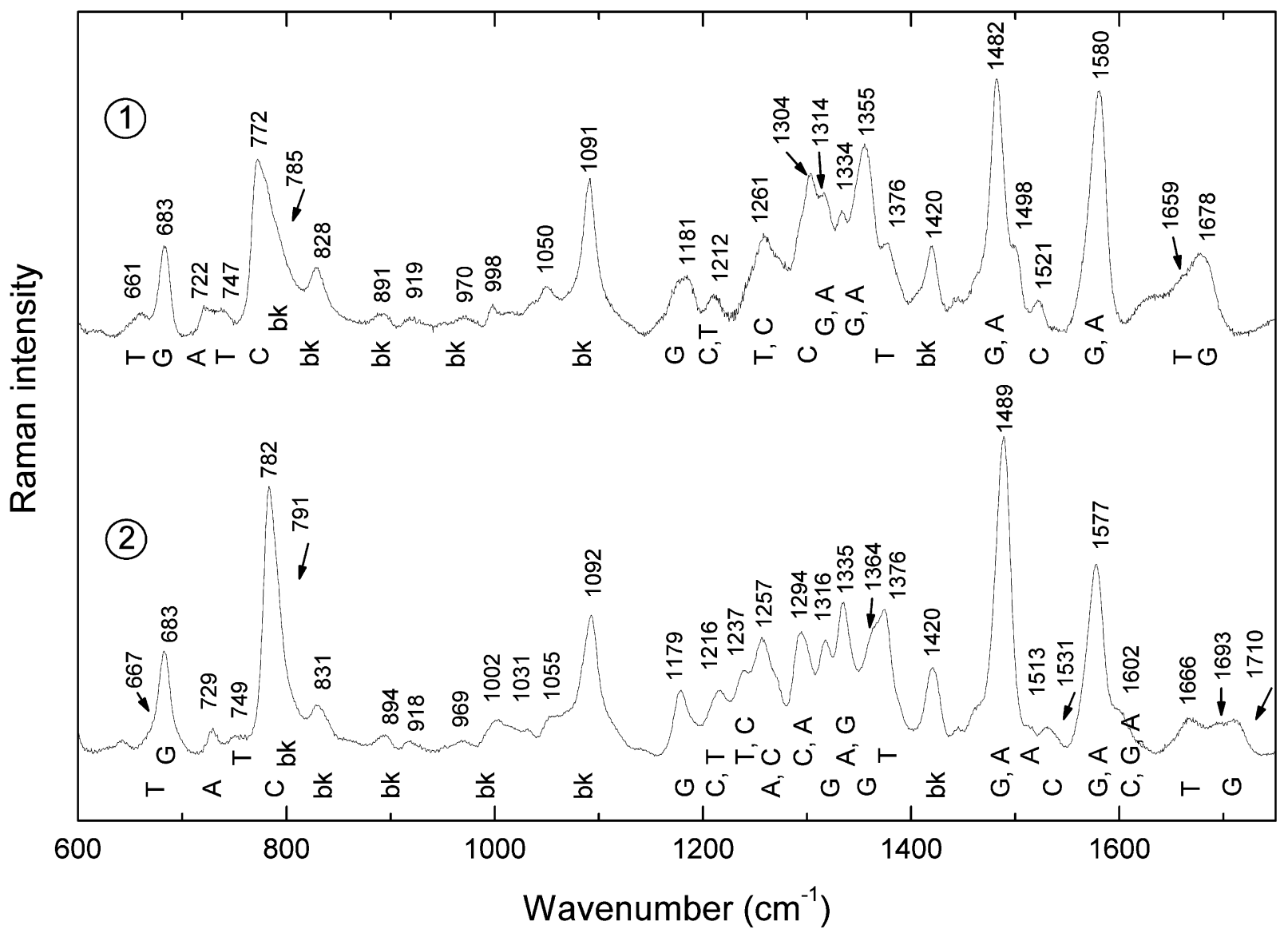

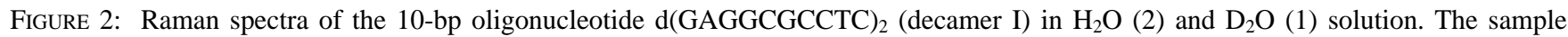
buffer is $50 \mathrm{mM}$ Tris- $\mathrm{HCl} \mathrm{pH} 7.3$ for spectrum 2 or pD 7.5 for spectrum 1 and $50 \mathrm{mM} \mathrm{NaCl}$; data were collected at $22{ }^{\circ} \mathrm{C}$ in the region $590-1750 \mathrm{~cm}^{-1}$. Concentrations are $12 \mathrm{mg} / \mathrm{mL}\left(\mathrm{H}_{2} \mathrm{O}\right)$ and $13 \mathrm{mg} / \mathrm{mL}\left(\mathrm{D}_{2} \mathrm{O}\right)$. Spectra were normalized with respect to the integrated intensity of the phosphate band near $1092 \mathrm{~cm}^{-1}$ and the adenine-guanine band near $1580 \mathrm{~cm}^{-1}(17,31)$. Peak positions of prominent Raman bands are labeled, the given wavenumbers are accurate to within $\pm 1 \mathrm{~cm}^{-1}$. Abbreviations are as follows: $\mathrm{G}$, guanine; T, thymine; $\mathrm{C}$, cytosine; A, adenine; bk, deoxyribose backbone.

The nucleoside conformation markers identify $\mathrm{C}^{\prime}$ endo/anti conformers. The spectra shown in Figure 2 are the signature of $\mathrm{d}(\mathrm{GAGGCGCCTC})_{2}$ and provide the basis for the interpretation of the difference spectra shown in Figure 5.

\section{Raman Signature of Sac7d}

The Raman spectrum of Sac7d in $\mathrm{H}_{2} \mathrm{O}$ (Figure 3, trace 2) is characterized by a strong amide I band $\left(1640-1680 \mathrm{~cm}^{-1}\right)$ centered at $1670 \mathrm{~cm}^{-1}$ and a broad, complex amide III band $\left(1230-1310 \mathrm{~cm}^{-1}\right)$ with a major contribution at $1242 \mathrm{~cm}^{-1}$ and weak shoulders at 1250 (irregular structures), 1268, 1285, and $1306 \mathrm{~cm}^{-1}$ ( $\alpha$-helix). The features of the amide I and amide III bands indicate $\beta$-strands as the main secondary structure elements of Sac7d. Calculation of the Sac7d secondary structure on the basis of the amide I band intensity profile (18) gives $50 \pm 4 \% \beta$-strand, $15 \pm 4 \% \alpha$-helix, and $35 \pm 3 \%$ irregular structures. The data are in agreement with the crystal structure of Sac7d (6). Figure 3 shows the Raman spectrum of Sac7d in fully protonated (nonexchanged) form measured in $\mathrm{H}_{2} \mathrm{O}$ buffer (trace 2) and the Raman spectrum of the partially deuterated Sac7d obtained in $\mathrm{D}_{2} \mathrm{O}$ (trace 1). Trace 3 shows the computed Raman difference spectrum (trace 1 minus trace 2) and represents the native exchange, that is, the exchange of hydrogen atoms that are exchangeable in the folded state of Sac7d. Information about the secondary structure of natively exchanged and protected sites of Sac7d can be deduced from the large difference features at the positions of the amide I and amide III bands (in $\mathrm{H}_{2} \mathrm{O}$ ) and the positions of the amide $\mathrm{I}^{\prime}$ and amide III' bands (in $\mathrm{D}_{2} \mathrm{O}$ ). The Raman intensity at the positions of the amide III and amide I bands is reduced and causes troughs in the difference spectrum.

Concomitantly, the Raman intensity at the positions of the amide III' $^{\prime}$ and amide $\mathrm{I}^{\prime}$ bands is increased and gives rise to difference peaks. Several trough/peak features are caused by the native state-deuteration induced frequency shift of amide III to amide III'. The trough/peak feature near 1239 and 986 $\mathrm{cm}^{-1}$ is caused by $\beta$-strands, and that near 1251 and 926 $\mathrm{cm}^{-1}$ is caused by irregular structures. Deuteration of the few $\alpha$-helical secondary structures present in Sac7d results in complicated features at 1305, 1282, 1265, and $948 \mathrm{~cm}^{-1}$. In the amide III region of Sac7d remain weak bands because of incomplete deuteration under the applied conditions of native exchange. The features of the amide I and amide I' bands with trough and peak, respectively, near 1674 and 1658 or $1640 \mathrm{~cm}^{-1}$ provide additional Raman signatures for native (incomplete) deuterium exchange of secondary structure elements.

A very weak amide II band at $1550-1560 \mathrm{~cm}^{-1}$ (Figure 3-2) represents $\mathrm{N}-\mathrm{H}$ in-plane bending and $\mathrm{C}-\mathrm{N}$ stretching of the trans peptide group. Deuteration of those groups causes 


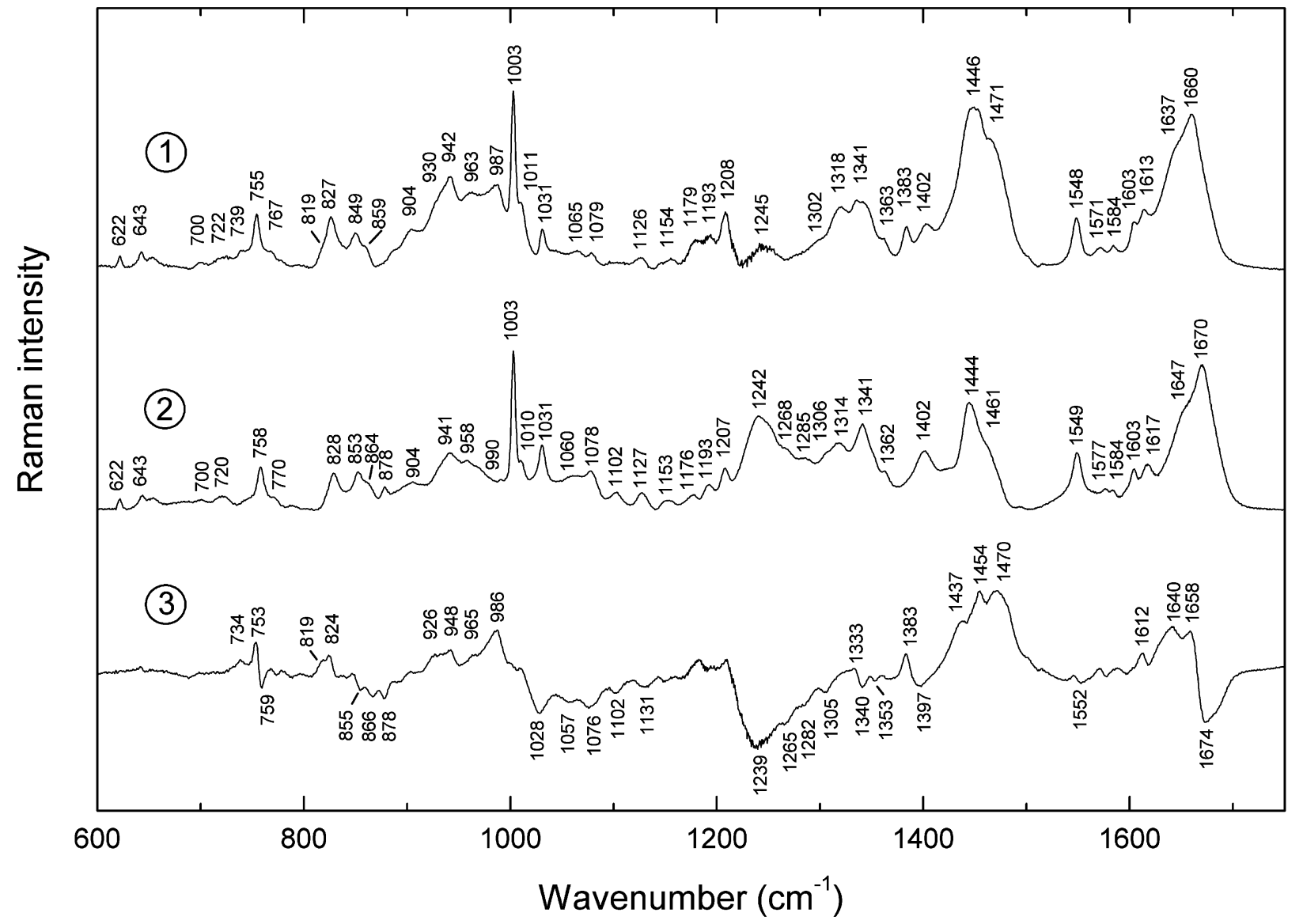

FIGURE 3: Raman spectra of Sac7d: (1) natively H $\rightarrow$ D exchanged Sac7d; (2) native Sac7d; (3) difference spectrum (spectrum 2 minus spectrum 1). Excitation at $488 \mathrm{~nm}$; spectral region $600-1750 \mathrm{~cm}^{-1}$; protein concentrations are $22 \mathrm{mg} / \mathrm{mL}\left(\mathrm{H}_{2} \mathrm{O}\right) \mathrm{and} 17 \mathrm{mg} / \mathrm{mL}\left(\mathrm{D}_{2} \mathrm{O}\right)$; buffers are $50 \mathrm{mM}$ Tris- $\mathrm{HCl}, \mathrm{pH} 7.5$ in $\mathrm{H}_{2} \mathrm{O}$ and $\mathrm{pD} 7.5$ in $\mathrm{D}_{2} \mathrm{O}$, and $50 \mathrm{mM} \mathrm{NaCl}$; data collection at $22{ }^{\circ} \mathrm{C}$. Spectra 1 and 2 were normalized to the integrated intensity of the phenylalanine band at $1003 \mathrm{~cm}^{-1}$, which is not affected by deuteration (20). For the calculation of the difference spectrum (spectrum 3), the normalized spectra (spectra 1 and 2) were subtracted such that the intensity at the phenylalanine band $1003 \mathrm{~cm}^{-1}$ becomes zero. Peaks in the difference spectrum (spectrum 3) appear when natively unprotected protons are exchanged against deuterons and the Raman bands are shifted. Peak positions of prominent Raman bands are labeled by the respective wavenumbers that are accurate to within $\pm 1 \mathrm{~cm}^{-1}$.

an intense amide II' band at $1471 \mathrm{~cm}^{-1}$ (Figure 3-1) and results in the most prominent feature of the difference spectrum with a peak at $1470 \mathrm{~cm}^{-1}$ (Figure 3-3). This band can be assigned to non- $\alpha$-helical (unprotected) sites of Sac7d (19).

Amino Acid Side Chains. The Raman spectra of Sac7d (Figure 3, traces 1 and 2) show typical contributions of aromatic side chains of one tryptophan, two phenylalanines, and two tyrosines and bands of nonaromatic amino acids (Table 1). Assignments were performed according to the literature (19-21 and references therein).

Environment of Tyrosine Side Chains. Two tyrosines, Y8 and Y34, are present in Sac7d. A tyrosine doublet at $\sim 850$ and $\sim 830 \mathrm{~cm}^{-1}$ (about the same position in $\mathrm{H}_{2} \mathrm{O}$ and $\mathrm{D}_{2} \mathrm{O}$ ) is caused by Fermi resonance of the normal mode $v_{1}$ (ring breathing fundamental) and the second harmonic $2 v_{16 a}$ (ring deformation overtone) of the para-substituted phenolic side chain (22).

The intensity ratio $I_{850} / I_{830}$ is sensitive to hydrogen bonding of phenolic $\mathrm{OH}$ groups and, therefore, is an indicator of the tyrosine environment. In the $\mathrm{H}_{2} \mathrm{O}$ spectrum (Figure 3-2) of Sac7d, two relatively sharp peaks of approximately equal intensity appear at 828 and $853 \mathrm{~cm}^{-1}$. The intensity ratio $I_{853} / I_{828}=1$ is in the range expected for tyrosines acting as both donor and acceptor of moderately strong or weak hydrogen bonds, as is the case when they are exposed to solvent $\mathrm{H}_{2} \mathrm{O}$ molecules (22). After $\mathrm{H} \rightarrow \mathrm{D}$ exchange (Figure $3-1)$ these bands marginally shift to 827 and $849 \mathrm{~cm}^{-1}$, respectively, and change the intensity profiles, with the band at $827 \mathrm{~cm}^{-1}$ becoming sharper and more intense than the band at $849 \mathrm{~cm}^{-1}$.

Tryptophan. The Trp vibrations are sensitive to the indole ring environment. Buried residues form sharp intense peaks, whereas the intensity is low for exposed residues. The position of the indole ring vibration at $878 \mathrm{~cm}^{-1}$ (called the W17 mode) of the unique Trp24 residue is indicative of exposed Trp residues with medium strong hydrogen bonds of the exocyclic Trp 1NH donors to water molecules. For the W17 mode, the frequency varies between 883 and 871 $\mathrm{cm}^{-1}$; without H-bonding at the N1 site of Trp this band is located at $883 \mathrm{~cm}^{-1}$, and with strong $\mathrm{H}$-bonding the band shifts to $871 \mathrm{~cm}^{-1}$ (23). In $\mathrm{D}_{2} \mathrm{O}$ buffer the $878 \mathrm{~cm}^{-1}$ band of Sac7d vanishes and a new $859 \mathrm{~cm}^{-1}$ band appears. A similar downshift on deuteration was observed for free tryptophan (24).

The frequency of the Trp band near $1549 \mathrm{~cm}^{-1}$ (called the W3 mode) assumes values between 1542 and $1557 \mathrm{~cm}^{-1}$ depending on the absolute value of the $\mathrm{C}_{\alpha} \mathrm{C}_{\beta}-\mathrm{C}_{3} \mathrm{C}_{2}$ torsion angle $\left|\chi^{2,1}\right|$, which varies between $60^{\circ}$ and $120^{\circ}(25)$. The position of the W3 mode does not vary in the spectra of 


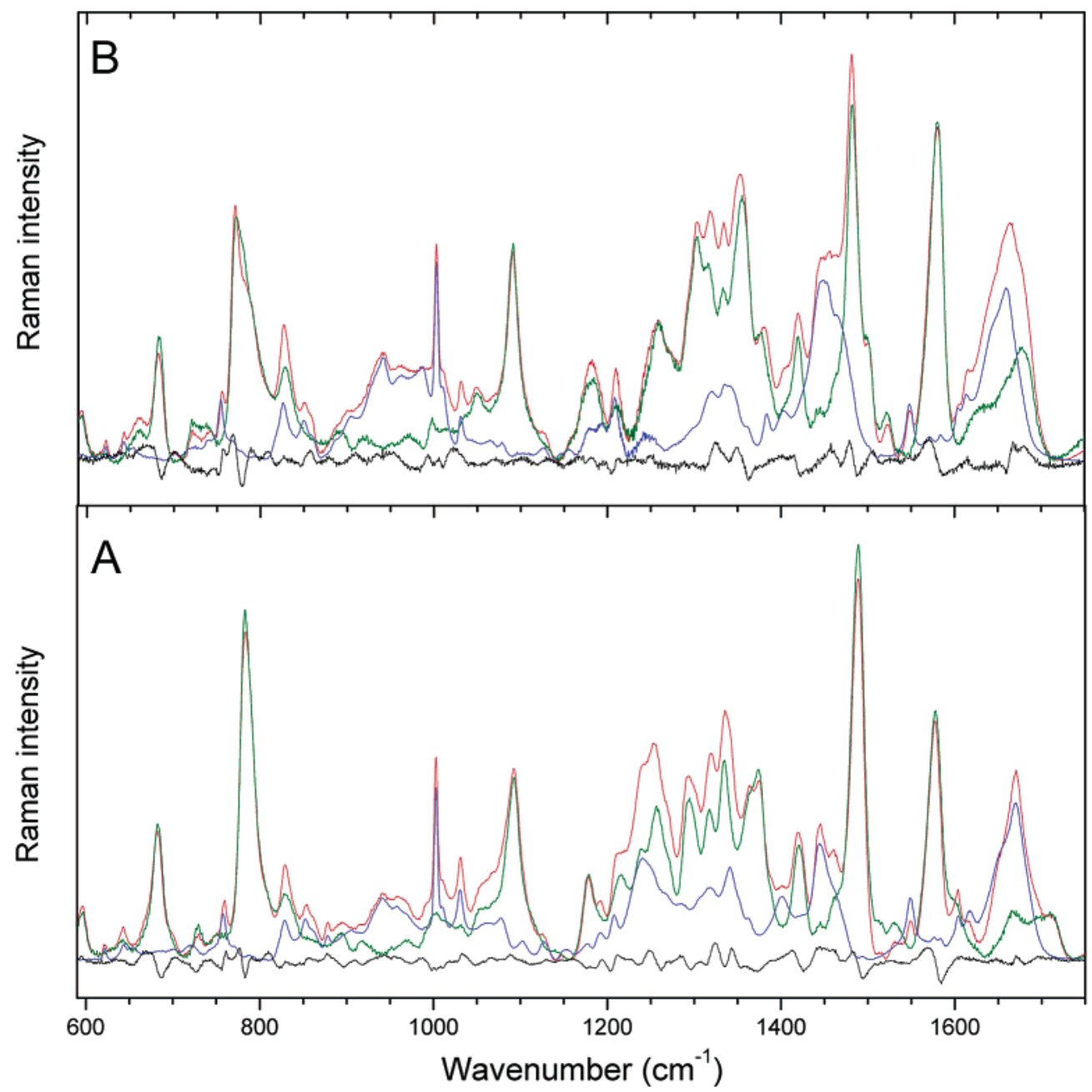

FIGURE 4: Raman spectra of Sac7d, d(GAGGCGCCTC) $)_{2}$, and the Sac7d-d(GAGGCGCCTC) ${ }_{2}$ complex (Sac7d-decamer I): (A) protein in $\mathrm{H}_{2} \mathrm{O}$ buffer; (B) protein in $\mathrm{D}_{2} \mathrm{O}$ buffer $\left(50 \mathrm{mM}\right.$ Tris- $\mathrm{D}_{2} \mathrm{O}$, $\mathrm{pH}$ or $\mathrm{pD} 7.5$, and $\left.50 \mathrm{mM} \mathrm{NaCl}\right)$. Protein concentrations are $50 \mathrm{mg} / \mathrm{mL}\left(\mathrm{H}_{2} \mathrm{O}\right)$ and $36 \mathrm{mg} / \mathrm{mL}\left(\mathrm{D}_{2} \mathrm{O}\right)$; spectra were excited at $488 \mathrm{~nm}$, and data were collected at $22{ }^{\circ} \mathrm{C}$ in the region $600-1750 \mathrm{~cm}^{-1}$. The blue traces show the Raman spectra of the isolated native and natively exchanged Sac7d from Figure 3. The green traces show the Raman spectra of decamer I from Figure 2. The red traces show the spectra of the Sac7d-d(GAGGCGCCTC) 2 complex. The black bottom traces show the computed difference spectra obtained by subtraction of the isolated component spectra from the experimental spectrum of the complex. The spectra are normalized to represent the same amounts of protein and DNA in the complex and in free form.

deuterated and nondeuterated samples, and its position of $1548 \pm 0.5 \mathrm{~cm}^{-1}$ indicates an average $\left|\chi^{2,1}\right|$ value of $\sim 88^{\circ}$.

The Fermi doublet of tryptophan with components at about 1360 and $1340 \mathrm{~cm}^{-1}$ (with similar positions in the $\mathrm{H}_{2} \mathrm{O}$ and $\mathrm{D}_{2} \mathrm{O}$ spectra) serves as a hydrophobicity marker. The upper $1360 \mathrm{~cm}^{-1}$ component of the doublet is strong in hydrophobic solvents whereas in a hydrophilic environment the lower $1340 \mathrm{~cm}^{-1}$ component is stronger. The intensity ratio, $R=$ $I_{1360} / I_{1340}$, is $<0.9$ for hydrophilic solvents and $>1.1$ for hydrophobic solvents (23). The intensity ratio is usually not detectable in proteins due to overlapping with bands caused by $\mathrm{CH}$ bending vibrations of aliphatic side chains. The Fermi doublet might be detected in difference spectra obtained by subtraction of the spectrum of the deuterated protein from that of the nondeuterated protein. Both bands of the doublet downshift by approximately $8 \mathrm{~cm}^{-1}$ upon deuteration (2324) that might result in detectable features of the difference spectrum. In fact, a very weak difference band near 1353 $\mathrm{cm}^{-1}$ and a relatively strong trough/peak feature at 1340/ $1333 \mathrm{~cm}^{-1}$ are visible in Figure 3-3, resulting from the downshift of both Fermi doublet components. The ratio, $R$ $\approx 0.5$, of the two bands of the Trp Fermi doublet is consistent with the presence of a surface localized tryptophan indole ring being exposed to the water molecules of the buffer.

Several other tyrosine and aliphatic amino acid side chains contribute to the Sac7d Raman spectra shown in spectra 1 and 2 of Figure 3. The assignments of Raman bands and corresponding $\mathrm{H} \rightarrow \mathrm{D}$ exchange wavenumbers are listed in Table 1.

\section{Raman Analysis of the Sac7d-d(GAGGCGCCTC $)_{2}$ Complex}

The Raman spectra of the Sac7d-d(GAGGCGCCTC) ${ }_{2}$ complex and its components are given in panels $\mathrm{A}$ and $\mathrm{B}$ of Figure 4. Panel A shows the Raman spectrum of fully protonated Sac7d, and panel B shows the spectrum of partially deuterated Sac7d. The blue, green, and red traces represent the spectra of Sac7d, d(GAGGCGCCTC) $)_{2}$, and the complex, respectively, as given before in Figures 2 and 3 . The black trace is the computed difference spectrum that was obtained by subtraction of the component spectra (green and blue traces) from the spectrum of the complex (red trace). Numerous peaks and troughs demonstrate spectral changes caused by complex formation between Sac7d and DNA. A 


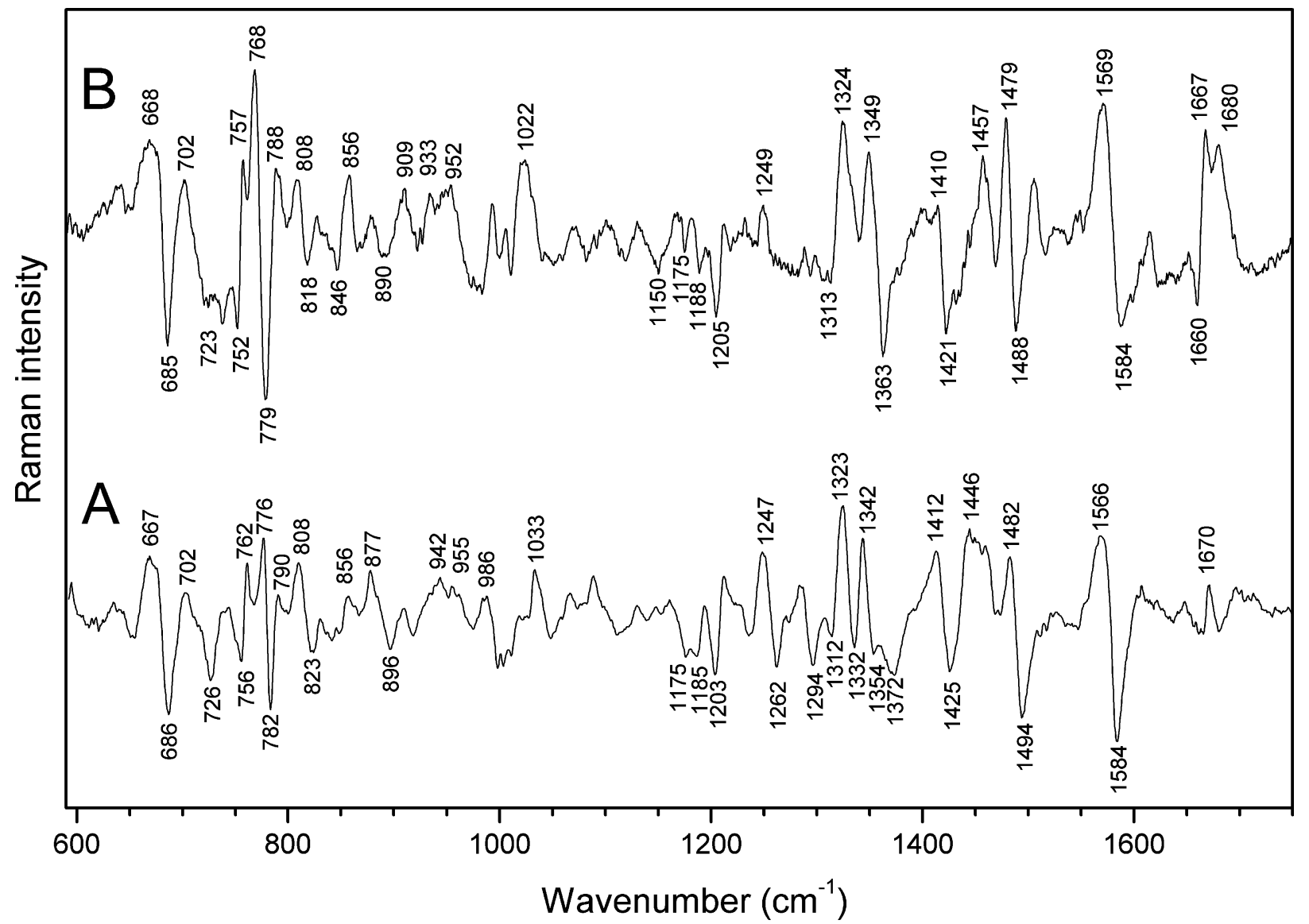

FIGURE 5: Enlarged Raman difference spectra (black bottom traces from Figure 4) of the Sac7d-decamer I complex in $\mathrm{H}_{2} \mathrm{O}$ buffer $(\mathrm{A})$ and in $\mathrm{D}_{2} \mathrm{O}$ buffer (B). Spectra were smoothed using the 11-point Savitsky-Golay algorithm.

Table 1: Vibrational Assignments for Raman Markers of Sac7d in $\mathrm{H}_{2} \mathrm{O}$ and $\mathrm{D}_{2} \mathrm{O}$ Solutions ${ }^{a}$

\begin{tabular}{|c|c|c|c|c|}
\hline $\mathrm{H}_{2} \mathrm{O}$ & $\mathrm{D}_{2} \mathrm{O}$ & assignment $^{b}$ & $\mathrm{H}_{2} \mathrm{O}$ & assignment $^{b}$ \\
\hline 622 & 622 & & 1153 & $1154 \mathrm{~V}, \mathrm{I}$ \\
\hline 643 & 643 & & 1176 & $1179 \mathrm{Y},\left[\mathrm{CH}_{3}\right]$ \\
\hline 654 & 653 & & 1193 & $1193 ?$ \\
\hline 700 & 700 & & 1207 & $1208 \mathrm{~F}, \mathrm{Y}$ \\
\hline 720 & 722 & & 1242 & 1245 AmIII (strand) \\
\hline 758 & 755 & & 1268 & AmIII (helix) \\
\hline 770 & 767 & W & 1285 & AmIII (helix) \\
\hline 828 & 827 & & 1306 & $1302\left[\mathrm{CH}_{2}\right]$, AmIII (helix) \\
\hline 853 & 849 & & 1314 & $1318\left[\mathrm{CH}_{2}\right]$ \\
\hline 878 & 859 & & 1341 & $1341\left[\mathrm{CH}_{2}\right]$ \\
\hline \multirow[t]{2}{*}{904} & 904 & $\mathrm{Q}, \mathrm{S}, \mathrm{T}$ & 1362 & $1363 \mathrm{~W}$ \\
\hline & 930 & AmIII (coil, turns) & & $1383 \mathrm{~W}$ \\
\hline 941 & 942 & K, V, L, AmIII (helix) & 1402 & $1402\left[\mathrm{COO}^{-}\right]$ \\
\hline \multirow[t]{2}{*}{958} & 963 & $\mathrm{~K}, \mathrm{~L}$ & 1444 & $1446 \mathrm{~K}, \mathrm{I}, \mathrm{L},\left[\mathrm{CH}_{2}\right]$ \\
\hline & 987 & AmIII (strand) & 1461 & $\mathrm{~A}, \mathrm{I}, \mathrm{V}, \mathrm{L}, \mathrm{W}, \mathrm{Y},\left[\mathrm{CH}_{2}\right]$ \\
\hline 990 & & I & & 1471 AmII \\
\hline 1003 & 1003 & & 1549 & $1548 \mathrm{~W}$ \\
\hline 1010 & 1011 & & 1577 & $1571 \mathrm{~W}$ \\
\hline 1031 & 1031 & & 1584 & $1584 \mathrm{~F}$ \\
\hline 1060 & 1065 & $\mathrm{~K}, \mathrm{~A}(\mathrm{C}-\mathrm{C}$ stretch$), \mathrm{F}$ & 1603 & $1603 \mathrm{~F}, \mathrm{Y}$ \\
\hline 1078 & 1079 & $\mathrm{C}-\mathrm{C}, \mathrm{C}-\mathrm{N}$ stretch & 1617 & $1613 \mathrm{~W}$ \\
\hline 1102 & & $\mathrm{P}, \mathrm{A}$ & 1647 & 1637 AmI (helix) \\
\hline 1127 & 1126 & I, V, L & 1670 & 1660 AmI (strand, coil) \\
\hline
\end{tabular}

${ }^{a}$ Raman data are from the Sac7d spectra shown in Figure 3. ${ }^{b}$ Assignments to specific amino acid side chains (one letter abbreviations) are based upon literature data (19-21). Square brackets indicate chemical group frequencies common to more than one type of side chain. Amide $(\mathrm{Am})$ modes are diagnostic of the indicated secondary structure.

positive difference peak indicates increased Raman intensity in the spectrum of the complex compared to the sum of component spectra, and a negative difference trough is caused by a lower intensity in the spectrum of the complex. When necessary, peak positions of deuterated samples will be given in parentheses.

Figure 5 shows the two amplified and, for clarity, smoothed difference spectra from Figure 4 (black traces) that are used for the further analysis. The features of the difference spectra provide information about conformational changes, structural rearrangements, and interactions between the components of the complex.

Backbone Conformation of d(GAGGCGCCTC $)_{2}$. The $700-900 \mathrm{~cm}^{-1}$ region is characteristic for Raman markers of DNA backbone geometry (15). The $782(772) \mathrm{cm}^{-1}$ peak in the Raman spectra of DNA is assigned to cytosine. The $791(785) \mathrm{cm}^{-1}$ peak is assigned to a stretching vibration of backbone phosphodiester groups and diagnostic of B-form DNA backbone geometry, specifically of torsion angles $\alpha$ and $\zeta$ in the gauche $e^{-}$range $(26-28)$. The $782 \mathrm{~cm}^{-1}$ cytosine and $791 \mathrm{~cm}^{-1}$ backbone bands overlap in the $\mathrm{H}_{2} \mathrm{O}$ spectrum of DNA to form a large $784 \mathrm{~cm}^{-1}$ peak. In $\mathrm{D}_{2} \mathrm{O}$, the frequency of the cytosine peak changes to $772 \mathrm{~cm}^{-1}$, and a broad band is formed with the backbone vibration that is indicated by a shoulder at $785 \mathrm{~cm}^{-1}$. The difference spectra show a prominent peak/trough/peak feature that is probably composed of contributions from the DNA backbone band and the cytosine band. Changes in the DNA backbone band result in the peak at 790 (788) $\mathrm{cm}^{-1}$ and the trough near $782(779) \mathrm{cm}^{-1}$, and cytosine causes the peak at $776(768) \mathrm{cm}^{-1}$ with the trough near $782(779) \mathrm{cm}^{-1}$. The corresponding features in the $\mathrm{D}_{2} \mathrm{O}$ 
difference spectrum (with band positions as given above in parentheses) support this assignment. The $\mathrm{H}_{2} \mathrm{O}$ and $\mathrm{D}_{2} \mathrm{O}$ difference features indicate small conformational perturbations to the $\mathrm{C}^{\prime}-\mathrm{O}^{\prime}-\mathrm{P}-\mathrm{O}^{\prime}-\mathrm{C} 3^{\prime}$ backbone network of DNA upon Sac7d binding. This is in agreement with previous observations $(26,29)$.

Deoxynucleoside Conformation of d (GAGGCGCCTC $)_{2}$. Sac7d binding alters the furanose ring geometry. The double stranded oligonucleotide d(GAGGCGCCTC) 2 used in this study is composed of $80 \%$ GC and $20 \%$ AT. The difference spectra (Figure 5) indicate perturbations of the deoxynucleoside conformation of GC and AT base pairs. A very small adenosine band at $729(722) \mathrm{cm}^{-1}$ is distorted under the influence of Sac7d binding. The intensity decrease of this band at $726(723) \mathrm{cm}^{-1}$ and a peak/trough feature at 1342/ 1332 (Figure 5A) indicate perturbations at dA. Difference features with trough/peak near 685/668 $\mathrm{cm}^{-1}$ and 1313/1324 $\mathrm{cm}^{-1}$ (Figure 5B) are consistent with small changes at $\mathrm{dG}$. Perturbations in cytosine nucleoside conformation markers are indicated in the difference spectra $\mathrm{A}\left(\mathrm{H}_{2} \mathrm{O}\right)$ and $\mathrm{B}\left(\mathrm{D}_{2} \mathrm{O}\right)$ by the respective peak/trough features at 776/782 (768/779) $\mathrm{cm}^{-1}$ and $1247 / 1262(1249 /-) \mathrm{cm}^{-1}$. Altogether, the observed spectral changes are consistent with partial transitions from $\mathrm{C}^{2}$-endo/anti to $\mathrm{C} 3$ '-endo/anti deoxynucleoside conformation at $\mathrm{dG}, \mathrm{dC}$, and dA. Similar shifts of those Raman markers accompany the canonical B- to A-form transition of DNA (30-32).

In DNA, for AT-rich sequences the phosphodiester B-form marker is located near $838-840 \mathrm{~cm}^{-1}$, for GC-rich sequences the corresponding marker occurs near $828-830 \mathrm{~cm}^{-1}$, and in the A-form DNA a phosphodiester marker appears near $807 \mathrm{~cm}^{-1}$ (14). In the difference spectrum of the Sac7d$\mathrm{d}(\text { GAGGCGCCTC) })_{2}$ complex a prominent difference peak/ trough feature at $808 / 823 \mathrm{~cm}^{-1}$ and a small peak at $856 \mathrm{~cm}^{-1}$ are indicative of a distortion of the DNA backbone and provide additional evidence for the backbone changes described above.

Deoxyribose Ring and Protein $\mathrm{CH}_{2} / \mathrm{CH}_{3}$ Vibrations. Furanose vibrations were identified in Raman spectra of DNA near 1420 and $1460 \mathrm{~cm}^{-1}$ and assigned to backbone vibrations $(26,31,33)$. In the spectrum of d(GAGGCGCCTC) 2 (Figure 2) the peak positions of those bands are at 1420 and 1461 $\mathrm{cm}^{-1}$. Protein bands are also located in this spectral region. $\mathrm{A} \mathrm{COO}^{-}$symmetric stretch vibration causes the $1402 \mathrm{~cm}^{-1}$ peak, and a very weak band at $1424 \mathrm{~cm}^{-1}$ reflects $\mathrm{CH}_{2}$ and $\mathrm{CH}_{3}$ deformations; at $1444 \mathrm{~cm}^{-1} \mathrm{CH}_{2}$ scissoring modes are found (traces 1 and 2 of Figure 3). The difference features visible in Figure 5 between 1410 and $1460 \mathrm{~cm}^{-1}$ may be assigned to backbone vibrations of the DNA and/or changes in the protein. X-ray structure analyses indicate that DNA binding does not cause any significant distortion to the protein secondary structure relative to the free protein in solution but only causes rearrangement of some protein side chains $(6,11)$. Since the protein contributions to the 1424 $\mathrm{cm}^{-1}$ band are very small, we conclude that vibrations of furanose residues are the main cause for the difference feature near $1420 \mathrm{~cm}^{-1}$, whereas the peak near $1450 \mathrm{~cm}^{-1}$ is mostly due to rearrangement of some protein side chains. The spectral effects might reflect either direct contacts of the furanose residues with protein side chains or conformational perturbations of the furanose rings. The difference feature near $1420 \mathrm{~cm}^{-1}$ shows about $20 \%$ intensity change, which implies that approximately two bases of each DNA strand undergo conformational perturbations $(16,26,29)$.

Purine Environment. The crystal structure of Sac7d with the oligonucleotide octamer d(GCGATCGC) 2 (Figure 1) indicates two direct contacts between protein residue Ser31 and guanine G3 in the minor groove (6). Ser31 forms a hydrogen bond with the $\mathrm{N} 2$ amino group of the guanine base at position $3(\mathrm{G} 3)$ that acts as the proton donor, and the indole $\mathrm{N} 1 \mathrm{H}$ group of Trp24 forms a specific hydrogen bond to G3N3 (6). A basically similar 3D structure is expected but still not available for the Sac7d-d(GAGGCGCCTC) 2 complex. In accordance with this expectation, prominent features in the difference spectra of the Sac7d-d(GAGGCGCCTC) 2 complex (Figure 5) are assignable to minor groove interaction of Sac7d with guanine N3.

Sac7d binding to guanine N2 and N3 causes changes of purine marker bands that result in the peak/trough features at $1342(1349) / 1354(1363) \mathrm{cm}^{-1}$ (overlapping with the tryptophan Fermi doublet and the adenosine conformation marker) and 1571(1569)/1587 (1584) $\mathrm{cm}^{-1}$ of the difference spectra (Figure 5). The band near $1355 \mathrm{~cm}^{-1}$ (in $\mathrm{D}_{2} \mathrm{O}$ ) was assigned to the guanine $\mathrm{ND}_{2}$ deformation vibration (34). The $\mathrm{D}_{2} \mathrm{O}$ difference spectrum (Figure 5B) clearly exhibits a peak/ trough difference feature at $1349 / 1363 \mathrm{~cm}^{-1}$; this feature is probably the spectral evidence for the contact of Ser31 with the N2 amino group of one or both guanines at positions 3 and/or 6 (see Discussion) in the minor groove. A similar feature but at higher wavenumber is expected to appear in the $\mathrm{H}_{2} \mathrm{O}$ spectrum, but instead that peak/trough feature arises at lower wavenumber at about 1342/1354 $\mathrm{cm}^{-1}$ (Figure 5A). A possible explanation is that the intense vibration of the $\mathrm{N} 2$ amino group of guanine (observed in $\mathrm{D}_{2} \mathrm{O}$ near 1355 $\mathrm{cm}^{-1}$ ) has in $\mathrm{H}_{2} \mathrm{O}$ two weak components (Figure 3-2): the first one near $1364 \mathrm{~cm}^{-1}$ (shoulder of the thymine $1376 \mathrm{~cm}^{-1}$ band) and the second one near $1348 \mathrm{~cm}^{-1}$ (shoulder of the adenine band near $1341 \mathrm{~cm}^{-1}$ ). A tryptophan contribution of the Fermi doublet is not excluded by this consideration but, in any case, is not completely responsible for the observed difference feature because of the downshift upon deuteration. Components of the Fermi doublet are expected to form difference bands in $\mathrm{H}_{2} \mathrm{O}$ solution near 1357 and 1340 $\mathrm{cm}^{-1}$ and in $\mathrm{D}_{2} \mathrm{O}$ near 1350 and $1333 \mathrm{~cm}^{-1}$ (24).

Unexpected is the appearance of a difference feature with a peak at $1482 \mathrm{~cm}^{-1}$ (in $\mathrm{D}_{2} \mathrm{O} 1479 \mathrm{~cm}^{-1}$ ) and a trough at $1494 \mathrm{~cm}^{-1}$ (in $\mathrm{D}_{2} \mathrm{O} 1488 \mathrm{~cm}^{-1}$ ) (Figure 5). This difference feature is a purine ring vibration of guanine N7 which was several times observed as a result of major groove DNA binding of proteins $(16-17,35-36)$. In the Sac7d$\mathrm{d}(\mathrm{GCGATCGC})_{2}$ system major groove binding is excluded by the X-ray structure analysis $(6-8)$, and by extrapolation it is rather unlikely for the Sac7d-d(GAGGCGCCTC) 2 complex. There are some possible explanations for the observed guanine N7 difference feature. First, Sac7d binding mediates an increase of the strength of the hydrogen bond of guanine N7 that is formed with a water molecule from the surroundings. Second, the guanine N7 ring vibration might be affected by the interactions of Sac7d with guanine ring N3 and/or N2 that are observed in the X-ray structure of the complex. Third, the B- to A-form transition of the DNA might cause a change in the guanine N7 vibration (32). The band near $1577 \mathrm{~cm}^{-1}$ (in $\mathrm{D}_{2} \mathrm{O} 1580 \mathrm{~cm}^{-1}$ ) is probably altered because of hydrogen bond formation between guanine 
$\mathrm{N} 3$ and the indole $\mathrm{N} 1 \mathrm{H}$ group of tryptophan that acts as proton donor.

Tryptophan. The Sac7d protein carries only one Trp residue (W24) that actively participates in binding of Sac7d to an 8-bp oligonucleotide (6) and thus facilitates the detection of key tryptophan markers in Sac7d-DNA complexes. Binding of Sac7d to d(GAGGCGCCTC $)_{2}$ results in spectral perturbations in tryptophan marker bands. In protein spectra, a Trp vibration called the W17 mode results in a band that is located between 883 and $871 \mathrm{~cm}^{-1}$, and a Trp band called the W18 mode is located around $761 \mathrm{~cm}^{-1}$. A tryptophan side chain in a hydrophilic environment gives rise to a very strong W18 band while in a hydrophobic environment the band becomes weaker (37).

In the spectrum of the Sac7d-d(GAGGCGCCTC $)_{2}$ complex, the W17 and W18 modes exhibit large spectral changes in comparison to the cases of the component spectra. However, the effects observed for the W17 and W18 modes show opposite tendencies in comparison to the expected ones. The interaction should increase the strength of the hydrogen bond and result in a downshift of the W17 band. The position of the W17 mode does not show this expected frequency shift; it is located at the same frequency $\left(878 \mathrm{~cm}^{-1}\right)$ as that in the spectrum of free Sac7d (Figure 5A), but the intensity of the band increases by about $30 \%$. This result is confirmed by the large intensity increase of the $\mathrm{W} 17$ mode in the $\mathrm{D}_{2} \mathrm{O}$ spectrum; the band is observed at $859 \mathrm{~cm}^{-1}$, in agreement with the $20 \mathrm{~cm}^{-1}$ shift described upon N1 deuteration (37). For the W18 mode an intensity increase is expected (37). To the contrary, the W18 mode does not increase its intensity but causes a very strong and sharp peak/trough feature at $762 / 756$ (in $\mathrm{D}_{2} \mathrm{O} 757 / 752$ ) $\mathrm{cm}^{-1}$ that indicates a downshift of the frequency. The changes observed here for the Sac7d$\mathrm{d}$ (GAGGCGCCTC $)_{2}$ system clearly indicate the participation of Trp24 in DNA binding despite of the differences in the behavior of the W17 and W18 modes in the lysozyme binding to inhibitors (37).

Sac7d Secondary Structure. In the difference spectra are no features that could be assigned to conformational changes of Sac7d upon complex formation. In the complex, amide III and amide I overlap with strong bands of DNA. Therefore, in some spectral regions it is difficult to discriminate between spectroscopic signals from protein or DNA. H $\rightarrow$ D exchange helps to assign at least the amide III band because it shifts from $1230-1310 \mathrm{~cm}^{-1}$ in $\mathrm{H}_{2} \mathrm{O}$ to the lower wavenumbers $\left(900-1000 \mathrm{~cm}^{-1}\right)$ of the amide III' band where DNA bands do not overlap. However, comparison of the $\mathrm{H}_{2} \mathrm{O}$ and $\mathrm{D}_{2} \mathrm{O}$ difference spectra does not exhibit clear spectral changes in the regions of the amide III band. We conclude that Sac7d has the same conformation in the complex and free in solution. This is in agreement with NMR data (11) and the results of the X-ray crystal structure analyses (6).

\section{DISCUSSION}

Raman spectroscopy of the Sac7d-d(GAGGCGCCTC) 2 complex indicates significant perturbations to the B-form DNA backbone as a consequence of Sac7d binding to the DNA decamer d(GAGGCGCCTC $)_{2}$. Several nucleotides (G, C, A) change their conformation from $\mathrm{C} 2^{\prime}$-endo/anti to C3'-endo/anti. Evidence for a partial transition from B- to A-form is found in several regions of the difference spectra.

\begin{tabular}{|c|c|c|c|c|c|c|}
\hline \multicolumn{3}{|c|}{$\begin{array}{l}\text { changes expected for the } \\
\text { B to A DNA transition }{ }^{b}\end{array}$} & \multirow[b]{3}{*}{ assignment } & \multirow{2}{*}{\multicolumn{3}{|c|}{$\begin{array}{l}\text { changes observed upon } \\
\text { complex formation }^{c}\end{array}$}} \\
\hline \multirow{2}{*}{$\begin{array}{l}\text { A-form } \\
\left(\mathrm{cm}^{-1}\right)\end{array}$} & & \multirow{2}{*}{$\begin{array}{l}\text { B-form } \\
\left(\mathrm{cm}^{-1}\right)\end{array}$} & & & & \\
\hline & & & & $\left(\mathrm{cm}^{-1}\right)$ & & $\left(\mathrm{cm}^{-1}\right)$ \\
\hline 665 & inc & & G & 667 & inc & \\
\hline & dec & 680 & G & & dec & 686 \\
\hline 781 & shift & 787 & $\mathrm{C}, \mathrm{bk}$ & 776 & shift & 782 \\
\hline 808 & inc & & C3'-endo & 808 & inc & \\
\hline & dec & 829 & $\mathrm{C} 2^{\prime}$-endo & & dec & 823 \\
\hline 1252 & shift & 1260 & $\mathrm{C}$ & 1247 & shift & 1262 \\
\hline 1314 & inc/shift & 1318 & $\mathrm{G}$ & 1312 & shift & 1323 \\
\hline 1334 & inc/shift & 1341 & A & 1332 & shift & 1342 \\
\hline 1417 & shift & 1420 & bk & 1412 & shift & 1425 \\
\hline 1482 & shift & 1489 & $\mathrm{G}$ & 1482 & shift & 1494 \\
\hline 1574 & shift & 1578 & G & 1566 & shift & 1584 \\
\hline
\end{tabular}

${ }^{a}$ Abbreviations: dec, decrease in intensity; inc, increase in intensity; shift, change in peak position; G, guanine; C, cytosine; A, adenine; bk, backbone. ${ }^{b}$ Raman data from ref 32. ${ }^{c}$ Raman difference features from Figure 5A.

Relevant spectral perturbations are summarized in Table 2. The phosphate band near $1092 \mathrm{~cm}^{-1}$ does not change significantly upon complex formation. The $1092 \mathrm{~cm}^{-1}$ band is commonly used as the intensity standard because of its invariance to effects of protein binding (38). By contrast, in complexes with minor groove binding proteins, slight broadenings of the phosphate band were observed that were interpreted to indicate changes in the local electrostatic environment (29). Since Sac7d binds in the minor groove of DNA octamers also for the Sac7d-d(GAGGCGCCTC) system, minor changes of the $1092 \mathrm{~cm}^{-1}$ band are not excluded. The identification of intensity differences is not possible in our experiments, since the $1092 \mathrm{~cm}^{-1}$ band was used as an intensity standard for spectra normalization. However, broadening might occur and would yield a peak/ trough like feature. This was not observed and suggests a conservation of the local electrostatic environment of the phosphates upon minor groove binding of Sac7d.

High resolution structures exist for several Sac7d-DNA octamer complexes. This provides the possibility to analyze the available Raman spectra in the context of the wealth of known structural details. Crystal structures were resolved of Sac7d and Sso7d complexes with seven different octameric oligonucleotides. Several observations are in common. The DNA was found sharply kinked at the C2pG3 step in the Sac7d-(5'-GCGATCGC $)_{2}$ complex, at the A3pA4 step in the Sac7d-(5'-GTAATTAC $)_{2}$ complex (6), and for a $\mathrm{T}-\mathrm{G}$ mismatched base pair at the T6pG7 step in the Sac7d- $\left(5^{\prime} \text {-GCGATTGC }\right)_{2}$ complex (7), and the base at the $3^{\prime}$ end of the intercalating site is always purine, with $\operatorname{Trp} 24$ $\mathrm{N} 1$ forming a hydrogen bond to its N3 atom. Kinks were not observed at the $\mathrm{GpC}$ or the GpT steps, likely because of their more favorable base-base stacking energies (7). The sequence of d(GAGGCGCCTC $)_{2}$ used for the present study does not contain TpG or ApA (TpT) steps.

The Raman results presented here show that in the Sac7d-d(GAGGCGCCTC) $)_{2}$ complex one of the guanines serves as a binding site, and it is reasonable that the $\mathrm{XpG}$ steps of the d(GAGGCGCCTC $)_{2}$ sequence serve as intercalation sites. Potential candidates are the A2pG3, G3pG4, and C5pG6 steps. It has been suggested previously that a preferred site for protein side chain binding might be 
connected with the base-base stacking energies (7). Up to now, to our knowledge base-base stacking energy calculations are not available that could be considered for a qualified discussion of the potential protein binding site in our system. In view of the size of d(GAGGCGCCTC $)_{2}$, the suggestion that the A2pG3 step could serve as a binding site implies the possibility that two Sac7d molecules bind to the oligonucleotide. However, gel electrophoresis of a complex formed in 1:1 molar stoichiometry did not provide any evidence in support of this assumption (data not shown).

The third base at the $3^{\prime}$ end of the intercalation site is a thymine that forms a hydrogen bond with its $\mathrm{O} 2$ thymine oxygen to $\operatorname{Arg} 43$ (7). In the d(GAGGCGCCTC) 2 sequence studied here, the third base at the $3^{\prime}$ ends of the two suggested intercalation sites is a cytosine. It is possible that Arg43 forms a hydrogen bond to cytosine $\mathrm{O} 2$, but the difference spectra do not provide feasible evidence for such a contact. It is not excluded from the data that Sac7d forms only two hydrogen bonds to guanine. The crystal structure of Sso7d-(5'-GTGATCGC $)_{2}$ shows that Arg43 NH1 is close to the third base (distance to T5-O2: $2.99 \AA$ ) and the fourth base (distances to C6-02 and C6-O4: 2.88 and $3.09 \AA$, respectively) at the $3^{\prime}$ ends of the intercalation sites (7). In the case that Sac7d kinks d(GAGGCGCCTC) 2 at the C5pG6 step, thymine is the fourth base at the $3^{\prime}$ end of the intercalation sites. The Sac7d Arg43 could be in a similar position as Arg43 of the Sso7d-(5'-GTGATCGC $)_{2}$ complex and form a hydrogen bond with $\mathrm{T} 9 \mathrm{O} 2$. This could increase the probability of forming a complex with the kink at the C5pG6 step.

The structural adjustment of DNA to Sac7d binding occurs with little or no apparent consequences to the secondary structure of Sac7d, suggesting an induced fit mechanism with a more flexible DNA conformation. This is consistent with the highly stable secondary structure of Sac7d that was confirmed by both NMR (11) and crystallographic (6) studies.

DNA minor groove binding by Sac7d generates large conformational perturbations in the DNA, including a kink of approximately $60^{\circ}$ and slight roll of roughly $10^{\circ}$, altogether making a bend of $\sim 70^{\circ}$ in the helical axis of $\mathrm{d}(\mathrm{GCGATCGC})_{2}$. Many nucleotides that surround the wedge site adopt the less common C3'-endo (N-type) sugar puckers (6). The DNA Raman spectrum responds with extraordinarily large perturbations, which are consistent with the crystal structures of Sac7d/Sso7d-DNA complexes $(6-8)$. These complexes exhibit unusual conformational features resembling those of A-DNA (as in an RNA duplex). The extent of the Raman changes is unusually high and varies from band to band. About $30 \%$ intensity changes relative to the parent bands were observed for Raman bands directly connected with nucleoside vibrations. The bands carrying information about base environments show $\sim 10-15 \%$ relative intensity changes. A direct quantitative analysis of B- to A-DNA partial transitions is difficult because of the complexity of the Raman signals, where the relevant bands overlap with contributions from base-base interaction and changes in the surroundings of the bases. Nevertheless, from the extent of the intensity changes, we estimate that two to six bases resemble an A-DNA like conformation. The Raman spectroscopic data provide evidence for the involvement of guanine, adenine, and cytosine in Sac7d-d(GAGGCGCCTC) 2 com- plex formation, directly by serving as hydrogen bond donor or acceptor or indirectly by changing their conformation. There is strong spectroscopic evidence for intercalation; however, it is not possible to determine the intercalation site. Potential sites are the A2pG3, G3pG4, and C5pG6 steps. It should be mentioned that neither Sac7d nor Sso7d crystallize so far as complexes with d(GAGGCGCCTC) $)_{2}$. Sac7d binding to more than one of the $\mathrm{A} 2 \mathrm{pG} 3, \mathrm{G} 3 \mathrm{pG} 4$, or C5pG6 sites and formation of heterogeneous mixtures of complexes would render crystallization difficult and explain this failure.

\section{ACKNOWLEDGMENT}

We thank Vladimír Kopecký Jr. for help with the secondary structure calculation of Sac7d.

\section{REFERENCES}

1. Charbonnier, F., and Forterre, P. (1994) Comparison of plasmid DNA topology among mesophilic and thermophilic eubacteria and archaebacteria, J. Bacteriol. 176, 1251-1259.

2. Lopez-Garcia, P., and Forterre, P. (1997) DNA topology in hyperthermophilic Archaea: reference states and their variation with growth phase, growth temperature and temperature stresses, Mol. Microbiol. 23, 1267-1279.

3. Baumann, H., Knapp, S., Lundback, T., Ladenstein, R., and Hard, T. (1994) Solution structure and DNA-binding properties of a thermostable protein from the archaeon Sulfolobus solfataricus, Nature Struct. Biol. 1, 808-819.

4. McAfee, J. G., Edmondson, S. P., Datta, P. K., Shriver, J. W., and Gupta, R. (1995) Gene cloning, expresion and characterisation of Sac7 proteins from hyperthermophile Sulfolobus acidocaldarius, Biochemistry 34, 10063-10077.

5. McAfee, J. G., Edmondson, S. P., Zegar, I., and Shriver, J. W. (1996) Equilibrium DNA binding of Sac7d protein from the hyperthermophile Sulfolobus acidocaldarius: fluorescence and circular dichroism studies, Biochemistry 35, 4034-4045.

6. Robinson, H., Gao, Y.-G., McCrary, B. S., Edmondson, S. P., Shriver, J. W., and Wang, A. H.-J. (1998) The hyperthermophile chromosomal protein Sa7d sharply kinks DNA, Nature 392, 202205 .

7. Su, S.-Y., Gao, Y.-G., Robinson, H., Liaw, Y.-C., Edmondson, S. P., Shriver, J. W., and Wang, A. H.-J. (2000) Crystal structures of the chromosomal proteins Sso/d/Sac7d bound to DNA containing T-G mismatched base-pairs, J. Mol. Biol. 303, 395-403.

8. Gao, Y.-G., Su, S.-Y., Robinson, H., Padmanabhan, S., Lim, L., McCrary, B. S., Edmondson, S. P., Shriver, J. W., and Wang, A. H.-J. (1998) The crystal structure of hyperthermophile chromosomal protein Sso7d bound to DNA, Nature Struct. Biol. 5, 782786.

9. Agback, P., Baumann, H., Knapp, S., Ladenstein, R., and Hard, T. (1998) Architecture of nonspecific protein-DNA interactions in the Sso7d-DNA complex, Nature Struct. Biol. 5, 579-584.

10. Krueger, J. K., McCrary, B. S., Wang, A. H.-J., Shriver, J. W., Trewhella, J., and Edmondson, S. P. (1999) The solution structure of the Sac7d/DNA complex: a small-angle X-ray scattering study, Biochemistry 38, 10247-10255.

11. Edmondson, S. P., Qiu, L., and Shriver, J. W. (1995) Solution structure of the DNA-binding protein Sac7d from the hyperthermophile Sulfolobus acidocaldarius, Biochemistry 34, 1328913304.

12. Bloomfield, V. A., Crothers, D. M., and Tinoco, I., Jr. (1999) Electronic and Vibrational Spectroscopy, Nucleic Acids, Structures, Properties, and Functions, pp 165-221, University Science Books, Sausalito, CA.

13. Dostál, L., Khare, D., Bok, J., Heinemann, U., Lanka, E., and Welfle, H. (2003) RP4 repressor protein KorB binds to the major groove of the operator DNA: A Raman study, Biochemistry 42, 14476-14482.

14. Thomas, G. J., Jr., and Tsuboi, M. (1993) Raman spectroscopy of nucleic acids and their complexes, Adv. Biophys. Chem. 3, 1-70.

15. Thomas, G. J., Jr., and Wang, A. H.-J. (1988) Laser Raman spectroscopy of nucleic acids, Nucleic Acids Mol. Biol. 2, 1-30.

16. Benevides, J. M., Li, T., Lu, X.-J., Srinivasan, A. R., Olson, W. K., Weiss, M. A., and Thomas, G. J., Jr. (2000) Protein DNA 
directed structure II. Raman spectroscopy of a leucine zipper bZIP complex, Biochemistry 39, 548-556.

17. Krafft, C., Hinrichs, W., Orth, P., Saenger, W., and Welfle, H. (1998) Interaction of Tet repressor with operator DNA and with tetracycline studied by infrared and Raman spectroscopy, Biophys. J. 74, 63-71.

18. Williams, R. W. (1986) Protein secondary structure analysis using Raman amide I and amide III spectra, Methods Enzymol. 130, $311-331$

19. Serban, D., Arcineigas, S. F., Vorgias, C. E., and Thomas, G. J., Jr. (2003) Structure and dynamics of the DNA-binding protein $\mathrm{HU}$ of B. stearothermophilus investigated by Raman and ultravioletresonance Raman spectroscopy, Protein Sci. 12, 861-870.

20. Overman, S. A., and Thomas, G. J., Jr. (1999) Raman markers of nonaromatic side chains in an $\alpha$-helix assembly: Ala, Asp, Glu, Gly, Ile, Leu, Lys, Ser, and Val residues of phage fd subunits, Biochemistry 38, 4018-4027.

21. Overman, S. A., and Thomas, G. J., Jr. (1998) Amide modes of $\alpha$-helix: Raman spectroscopy of filamentous virus fd containing peptide ${ }^{13} \mathrm{C}$ and ${ }^{2} \mathrm{H}$ labels in coat protein subunits, Biochemistry $37,5654-5665$.

22. Siamwiza, M. N., Lord, R. C., Chen, M. C., Takamatsu, T., Harada, I., Matsuura, H., and Shimanouchi, T. (1975) Interpretation of the doublet at 850 and $830 \mathrm{~cm}^{-1}$ in the Raman spectra of tyrosyl residues in proteins and certain model compounds, Biochemistry $14,4870-4876$.

23. Miura, T., Takeuchi, H., and Harada, I. (1988) Characterization of individual tryptophan side chains in proteins using Raman spectroscopy and hydrogen deuterium exchange kinetics, Biochemistry 27, 88-94.

24. Overman, S. A., and Thomas, G. J., Jr. (1998) Amide modes of the $\alpha$-helix: Raman spectroscopy of filamentous virus $f d$ containing peptide $13 \mathrm{C}$ and $2 \mathrm{H}$ labels in coat protein subunits, Biochemistry 37, 5654-5665.

25. Miura, T., Takeuchi, H., and Harada, I. (1989) Tryptophan Raman bands sensitive to hydrogen bonding and side-chain conformation, J. Raman Spectrosc. 20, 667-671.

26. Benevides, J. M., Chan, G., Lu, X.-J., Olson, W. K., Weiss, M. A., and Thomas, G. J., Jr. (2000) Protein-directed DNA structure. I. Raman spectroscopy of a high-mobility-group box with application to human sex reversal, Biochemistry 39, 537-547.

27. Benevides, J. M., Kukolj, G., Autexier, C., Aubrey, K. L., DuBow, M. S., and Thomas, G. J., Jr. (1994) Secondary structure and interaction of phage D108 Ner repressor with a 61-base-pair operator: Evidence for altered protein and DNA structures in the complex, Biochemistry 33, 10701-10710.
28. Movileanu, L., Benevides, J. M., and Thomas, G. J., Jr. (1999) Temperature dependence of the Raman spectrum of DNA. Part I-Raman signatures of premelting and melting transitions of poly(dA-dT)·poly(dA-dT), J. Raman Spectrosc. 30, 637-649.

29. Serban, D., Benevides, J. M., and Thomas, G. J., Jr. (2003) HU protein employs similar mechanisms of minor-groove recognition in binding to different B-DNA sites: Demonstration by Raman spectroscopy, Biochemistry 42, 7390-7399.

30. Benevides, J. M., and Thomas, G. J., Jr. (1983) Characterization of DNA structures by Raman spectroscopy: High-salt and lowsalt forms of double helical poly (dG-dC) in $\mathrm{H}_{2} \mathrm{O}$ and $\mathrm{D}_{2} \mathrm{O}$ solutions and application to B-, Z- and A-DNA, Nucleic Acids Res. 11, 5747-5761.

31. Prescott, B., Steinmetz, W., and Thomas, G. J., Jr. (1984) Characterization of DNA structures by Raman spectroscopy, Biopolymers 23, 235-256.

32. Peticolas, W. L., and Evertsz, E. (1992) Conformation of DNA in vitro and in vivo from laser Raman scattering, Methods Enzymol. 211, 335-352.

33. Thomas, G. J., Jr., Benevides, J. M., Overman, S. A., Ueda, T., Ushizawa, K., Saitoh, M., and Tsuboi, M. (1995) Polarized Raman spectra of oriented fibres of A-DNA and B-DNA: Anisotropic and isotropic local Raman tensors of base and backbone vibrations, Biophys. J. 68, 1073-1088.

34. Krafft, C., Benevides, J. M., and Thomas, G. J., Jr. (2002) Secondary structure polymorphism in Oxytricha nova telomeric DNA, Nucleic Acids Res. 30, 3981-3991.

35. Benevides, J. M., Weiss, M. A., and Thomas, G. J., Jr. (1991) Design of the helix-turn-helix motif: Nonlocal effects of quaternary structure in DNA recognition investigated by laser Raman spectroscopy, Biochemistry 30, 4381-4388.

36. Benevides, J. M., Weiss, M. A., and Thomas, G. J., Jr. (1994) An altered specificity mutation in the $\lambda$ repressor induces global reorganization of the protein-DNA interface, J. Biol. Chem. 269, 10869-10878

37. Miura, T., Takeuchi, H., and Harada, I. (1991) Raman spectroscopic characterization of tryptophan side chains in lysozyme bound to inhibitors: Role of hydrophobic box in the enzymatic function, Biochemistry 30, 6074-6080.

38. Benevides, J. M., Weiss, M. A., and Thomas, G. J., Jr. (1991) DNA recognition by the helix-turn-helix motif: investigation by laser Raman spectroscopy of the phage $\lambda$ repressor and its interaction with operator sites $\mathrm{O}_{\mathrm{L}} 1$ and $\mathrm{O}_{\mathrm{R}} 3$, Biochemistry 30 , $5955-5963$.

BI049192R 